\title{
2 ．房室回帰頻拍におけるリエントリー路の形成
}

加藤林也* 鈴木正之*

\begin{abstract}
房室回帰頻拍（AVRT）に扔けるリエントリー路の形成を検討するため, 副伝導路を有する例 において, 心房の不応期 (AERP) と心房 echo 出現時の房室伝導時間 (AVCT) を検討した. 顕在性 WPW 症候群の 6 例では, 副伝導路の順伝導が途絶し, AVCT $(236.7 \pm 29.6 \mathrm{msec})$ が AERP $(211.7 \pm 24.8 \mathrm{msec})$ より長くなった早期刺激時に心房 echo が生じた. 房室結節内二重伝導路を有 する潜在性 WPW 症候群 4 例では, 全例で fast pathway の不応期に一致して心房 echo が生じた.

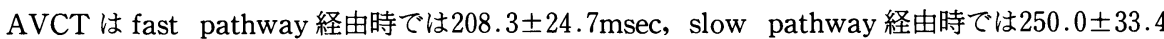


AVCT はAERP と近似していた（220.0 $27.8 \mathrm{vs} 226.3 \pm 31.6 \mathrm{msec})$. 以上よりAVRTにおけ るリエントリー路の形成には副伝導路での一方向性ブロックと，心房筋の不応期を凌駕する房室 伝導遅延が不可欠であることが確認された。
\end{abstract}

不整脈の発生機序として考えられているリエン トリーは，興奮旋回路内での一方向性ブロックと 伝導障害の併存により成立するとされている，リ エントリー性頻拍では，(1)プログラム刺激により 再現性をもって頻拍の誘発，停止が可能であり， (2)一定の早期刺激間隔による頻拍誘発域があり, (3)頻拍誘発時の早期刺激間隔と早期刺激から頻拍 開始までの間隔には逆相関がみられ，(4)頻拍中の 電気刺激により entrainment 現象がみられるなど の電気生理学的特徵がみられている ${ }^{1) \sim 3)}$. 臨床的に はリエントリー路を形成する複数の伝導路と前述 の電気生理学的特徵を確認することで診断される. ここでは解剖学的にも旋回路の成立が最も理解し やすい副伝導路を有する例をモデルとして, 房室 回帰頻拍における一方向性ブロックと伝導遅延に よるリエントリー路の形成について検討した.

\section{I ．対象および方法}

対象は心房早期刺激により刺激興奮が房室結節 を順行し, 副伝導路を逆行する上室頻拍が誘発さ れた副伝導路症候群 23 名であり, その内訳は顕在

* 名古屋大学医学部第 1 内科

（テ466 名古屋市昭和区鶴舞町65）
性 WPW 症候群 (M 群) 6 名, 潜在性 WPW 症候 群 (C 群) 17名, 男 20 名, 女 3 名, 年齢は $21 \sim 74$ 歳 (平均年齢 $47.7 \pm 15.9$ 歳) であった。

右大腿静脈および左鎖骨下静脈より双極または 4 極のカテーテル電極を心腔内に挿入し, 高位右 房 (HRA), ヒス束電位記録部 (HBE), 冠静脈内 (CS), 右室心尖部（RVA）にそれぞれ留置した。 通常の方法で電気生理学的検查を施行し, 原則と して基本刺激間隔 $600 \mathrm{msec}$ での高位右房単発早期 刺激法により, 心房有効不応期 (AERP), 副伝導 路順行性不応期 (AntERP), 房室結節有効不応期 (AVNERP), 右室有効不応期 (RVAERP), 心房 エコーを誘発した早期刺激間隔の上限 $\left(\operatorname{maxS}_{1}-\mathrm{S}_{2}\right)$ とその時の正常房室伝導時間（副伝導路付着部近 傍の AV 時間：AVAe）および心房エコーを誘発 する直前の正常房室伝導時間 (AVNe) を測定し, 房室回帰頻拍における興奮旋回路の形成に関与す る一方向性ブロックの存在と伝導遅延の程度を検 討した.

$\begin{aligned} \text { Keywords } & \\ & \text { 房室回㷌頻拍 } \\ \text { リエントリー } & \text { 一方向性ブロック } \\ & \text { 伝導遅延 } \\ & \text { 副伝導路 }\end{aligned}$


表 1 顕在性副伝導路症候群

\begin{tabular}{|c|c|c|c|c|c|c|}
\hline 例数 & ant ERP & $\max S 1-S 2$ & AVAe & AERP & AVAe-AERP & AVNe-AERP \\
\hline \multirow[t]{2}{*}{$N=6$} & 280.0 & 265.8 & 236.7 & 211.7 & 25.0 & -30.0 \\
\hline & \pm 21.7 & \pm 12.8 & \pm 29.6 & \pm 24.8 & \pm 20.5 & \pm 42.4 \\
\hline
\end{tabular}

Mean \pm SD

Abbreviations ; antERP=副伝導路順行性不応期, $\max \mathrm{S}_{1}-\mathrm{S}_{2}$ 二心房エコーを生じた最大 早期刺激間隔, $\mathrm{AVAe}=$ 心房エコー出現時の房室伝導時間, $\mathrm{AVNe}=$ 心房 エコー出現直前の房室伝導時間, $\mathrm{AERP}=$ 心房不応期

表 2 房室結節内二重伝導路を有する潜在性副伝導路症候群

\begin{tabular}{rrrrrrrr}
\hline & $\beta-E R P$ & maxS1-S2 & AVAe & AERP & AVNe & AVAe-AERP & AVNe-AERP \\
\hline \multirow{2}{*}{$\begin{array}{rrrr}3 \\
\end{array}$} & 388.8 & 388.8 & 250.0 & 226.3 & 208.3 & 23.8 & -25.0 \\
& \pm 75.5 & \pm 75.5 & \pm 33.4 & \pm 14.9 & \pm 24.7 & \pm 23.2 & \pm 22.9 \\
\hline
\end{tabular}

Mean \pm SD

Abbreviations : $\quad \beta$ - $\mathrm{ERP}=$ 房室結節 fast pathway の不応期, $\operatorname{maxS}_{1}-\mathrm{S}_{2}$ =心房エコーを生 じた最大早期刺激間隔, $\mathrm{AVAe}=$ 心房エコー出現時の房室伝導時間, $\mathrm{AERP}=$ 心房不応期, $\mathrm{AVNe}=$ 心房エコー出現直前の房室伝導時間

表 3 潜在性副伝導路症候群

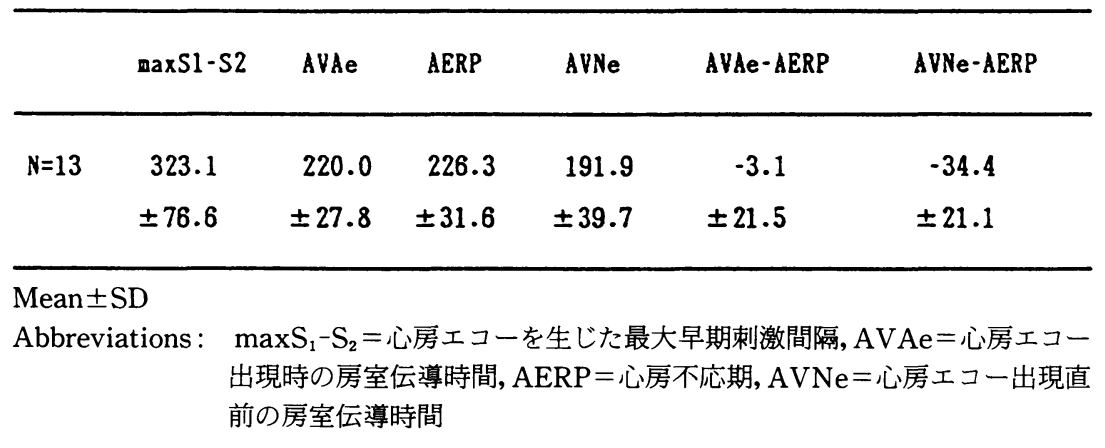

\section{II. 結果 (表 1)}

電気生理学的検査により, C 群の 4 例では房室結 節内二重伝導路が認められ,これらを DC 群とし, 他の13例を SC 群 $(n=13)$ として分類し, 以下の 結果を得た。

(1) M 群では AERP は211.7 $\pm 24.8 \mathrm{msec}$, Ant

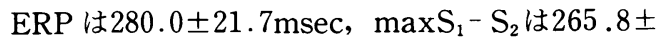

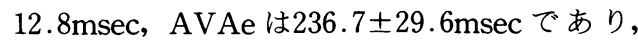
AVAe は AERPより 25.0 $20.5 \mathrm{msec}$ 長く, AVNe は AERP より $30.0 \pm 42.4 \mathrm{msec}$ 短かった。 $\mathrm{M}$ 群の 6 例中 4 例で AntERP と $\operatorname{maxS}_{1}-\mathrm{S}_{2}$ が一致
し, 副伝導路の順行性不応期に一致して心房エコ 一が生じたが, 他の 2 例では副伝導路の順伝導が 途絶しても直ちには心房エコーは生じなかった。

(2) 房室結節内二重伝導路を認めた DC 群では全 例にて房室結節内の速い伝導路 (fast pathway) の有効不応期 $\left(\beta\right.$-ERP) と $\operatorname{maxS}_{1}-\mathrm{S}_{2}$ が一致した.

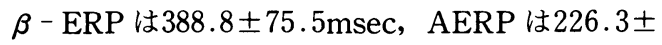
14.9msec, AVAe は250.0さ33.4msec, AVNeは $208.3 \pm 24.7 \mathrm{msec}$ であり, AVAe は AERPより $23.8 \pm 23.2 \mathrm{msec}$ 長く, AVNe は AERPより $25.0 \pm 22.9 \mathrm{msec}$ 短かった. DC 群では全例で房室 

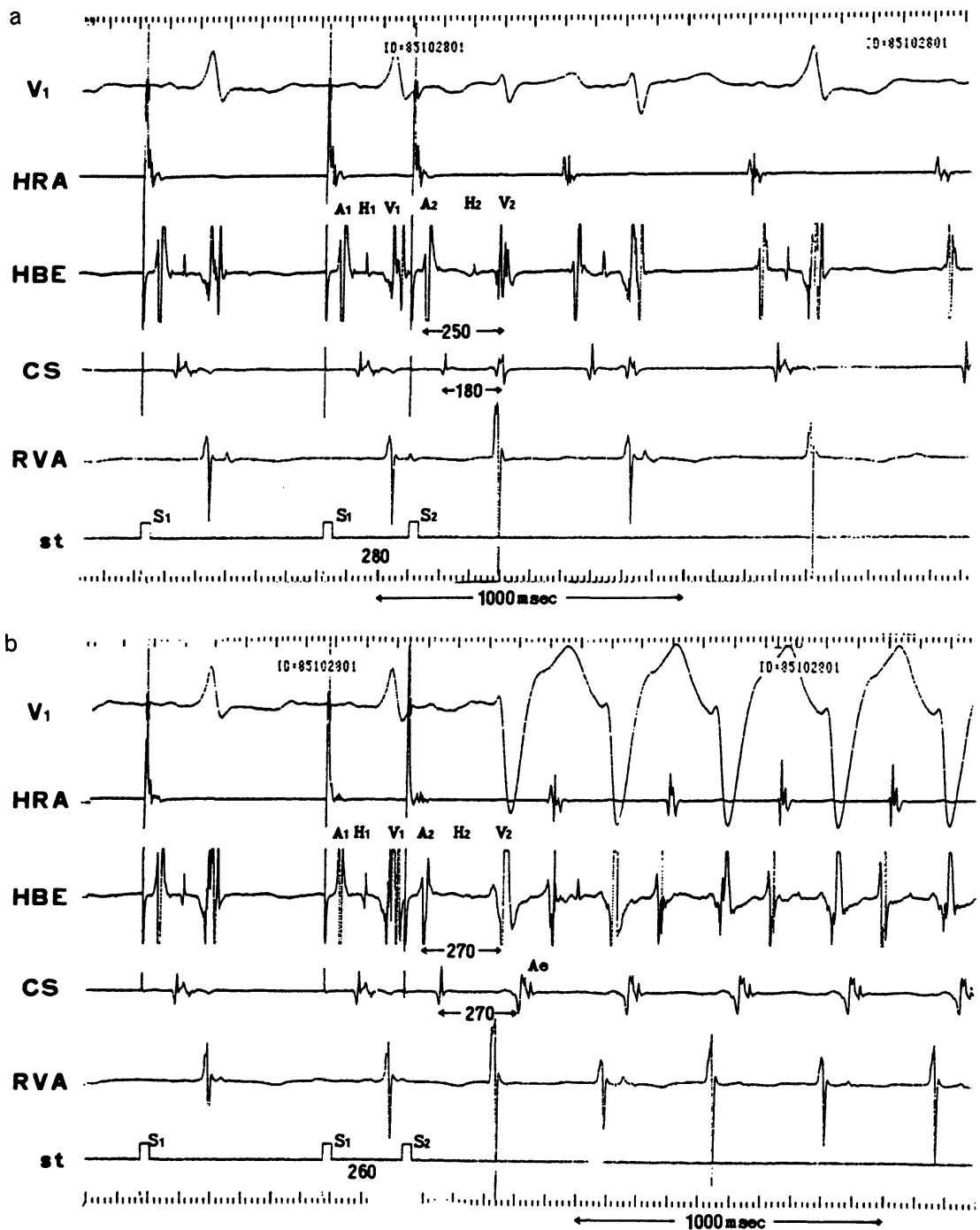

図 1 顕在性副伝導路症候群における頻拍の誘発

図上段（a）は基本刺激間隔 $\left(\mathrm{S}_{1}-\mathrm{S}_{1}\right) 600 \mathrm{msec}$ ，早期刺激間隔 $\left(\mathrm{S}_{1}-\mathrm{S}_{2}\right) 280 \mathrm{msec} て ゙$ の記録である. 副伝導路の不応期のため, 早期刺激による QRS 波形はデルタ波が消 失し, 正常化しているが, 房室伝導時間は $180 \mathrm{msec}$ と心房不応期 $(200 \mathrm{msec})$ より短

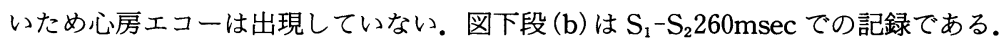
早期刺激間隔のわずかな短縮によっても房室伝導時間は $270 \mathrm{msec}$ と延長し, 心房不 応期を脱し, 心房エコーが出現し, 房室回帰頻拍が誘発されている. 図中の記録は, $\mathrm{V}_{1}$ : 体表面心電図 ( $\mathrm{V}_{1}$ 誘導), HRA : 高位右房, HBE : 七ス束電位図, $\mathrm{CS}$ : 冠静脈 洞，RVA：右室心尖部での電位記録，である(以下同じ).

結節内 fast pathway の不応期に一致して潜在性副 伝導路を介した心房エコーが生じた。

(3) $\mathrm{SC}$ 群の AERP は226.3 $\pm 31.6 \mathrm{msec}, \mathrm{maxS}_{1}$

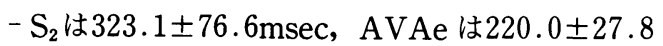

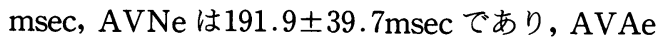

は AERPより $3.1 \pm 21.5 \mathrm{msec}$ 短く, AVNe は AERP より 34.4 $21.1 \mathrm{msec}$ 短かった. SC 群では 頻拍誘発時点での早期刺激間隔のわずかな短縮に 伴う $\mathrm{AV}$ 時間の延長分は $23.3 \pm 22.5 \mathrm{msec}$ であり, $50 \mathrm{msec}$ 以上の突然の延長を認めたのは 13 例中 HV 


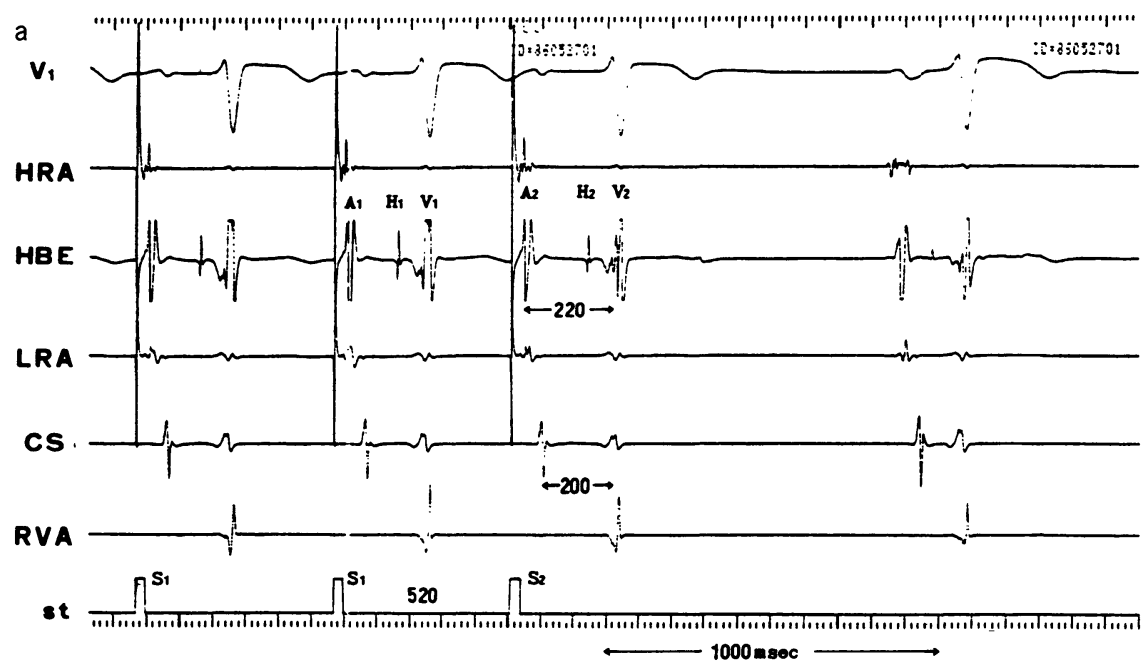

b $\quad$ b...1

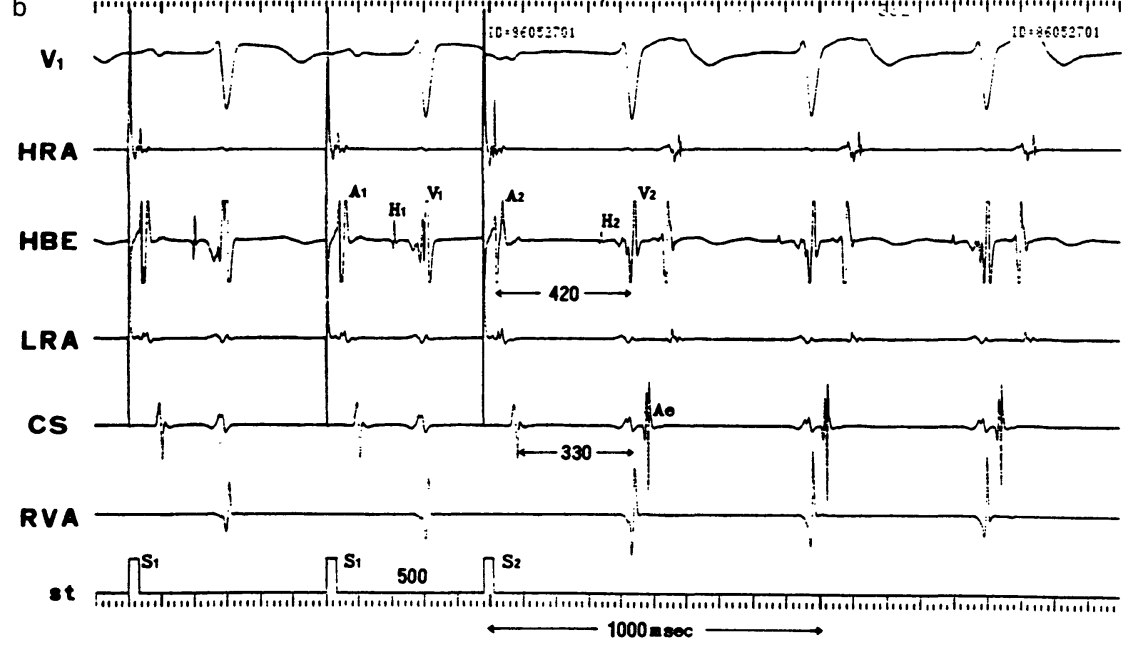

図 2 潜在性副伝導路症候群（房室結節内二重伝導路合併例）における頻拍の誘発

図上段 (a) は $\mathrm{S}_{1}-\mathrm{S}_{1}: 600 \mathrm{msec}, \mathrm{S}_{1}-\mathrm{S}_{2}: 520 \mathrm{msec}$ での記録である. 房室伝導時間は $\beta$ 路（fast pathway）経由のため $200 \mathrm{msec}$ と心房不応期（240msec）より短く，心 房エコーは出現していない. 図下段 (b) は $\mathrm{S}_{1}-\mathrm{S}_{2}: 500 \mathrm{msec}$ での記録であるが, 房 室結節内 $\beta$ 路の不応期のため, 房室伝導は $\alpha$ 路経由となり, 房室伝導時間は $330 \mathrm{msec}$ と著明に延長し, 心房不応期を脱するのに十分な伝導遅延となり, 心房エコーが出 現し，房室回㷌頻拍が誘発されている。

図中の記録は LRA：低位右房, その他は図 1 と同様である.

時間が延長した 1 例のみであった.

\section{III. 考 察}

リエントリーは, 興奮旋回路内での一方向性ブ ロックと伝導障害の併存により成立するとされて いる. 房室回帰頻拍例における興奮旋回路は，心 房，房室結節，心室，および副伝導路より成り， 順行性房室伝導は房室結節を, 逆行性室房伝導は
副伝導路を経由する場合には，副伝導路での一方 向性ブロックと, 房室結節内での伝導遅延がリエ ントリーの必要条件と考えられるが, 房室結節で の伝導遅延が excitable gap となる心筋組織の不応 期より長いことがリエントリー路を形成するのに 必要である.

本研究に用いた顕在性副伝導路症候群では, 副 伝導路の順行性不応期が, いずれも房室結節の不 

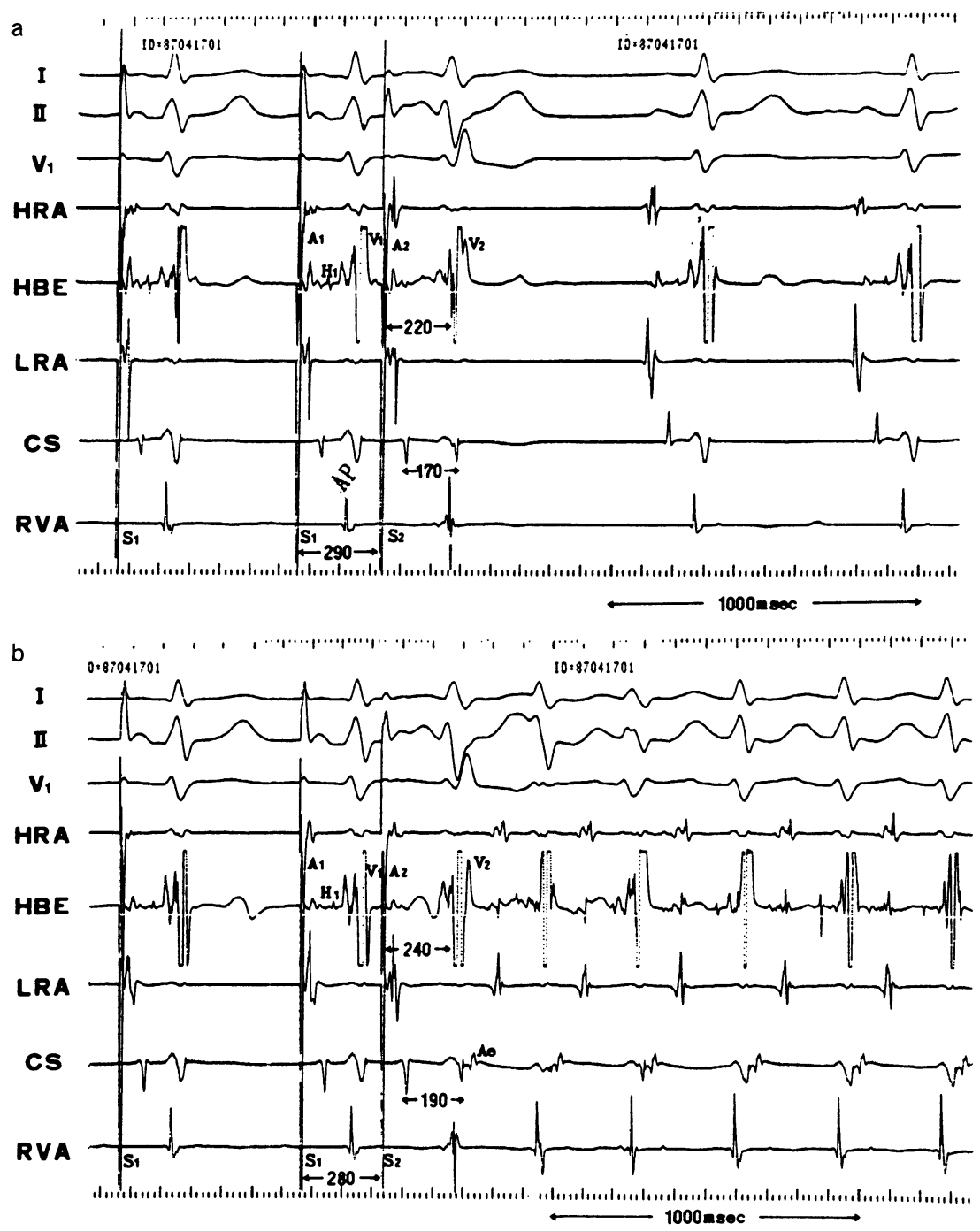

図 3 潜在性副伝導路症候群における頻拍の誘発

図上段 (a) は $\mathrm{S}_{1}-\mathrm{S}_{1}: 600 \mathrm{msec}, \mathrm{S}_{1}-\mathrm{S}_{2}: 290 \mathrm{msec}$, 下段 (b) は $\mathrm{S}_{1}-\mathrm{S}_{2}: 280 \mathrm{msec}$ で の記録である. 早期刺激間隔の短縮による房室伝導時間の延長 ( $170 \mathrm{msec} v \mathrm{vs} 190 \mathrm{msec})$ はわずかであるにもかかわらず，冠静脈洞での記録では早期刺激による心室電位の 直後に左後下壁を最早期興奮部位とする心房エコーが生じ, 頻拍が開始している. 房室伝導時間のわずかな延長により, 副伝導路近傍の心房筋 (CS) の不応期を脱し たかまたは早期刺激により，不応期が短縮したため，心房エコーが出現し，房室回 帰頻拍が誘発されたと考元られる (本文参照). 図中の記録は図 2 と同様である.

応期より長く, 6 例中 4 例では副伝導路の不応期, すなわち副伝導路でのブロックが生じた時点で心 房エコーを生じた。一方，他の 2 例では副伝導路 でのブロックを生じた時点では直ちに心房エコー を生じなかった。穴エコーを生じた早期刺激時 の房室伝導時間 (平均 $245 \mathrm{msec}$ ) は心房不応期 (平
均 $215 \mathrm{msec}$ ) より長く, 前述の 2 例での心房エコー 出現直前の早期刺激時の房室伝導時間（平均 175 $\mathrm{msec}$ ）は心房不応期（平均 $205 \mathrm{msec}$ ）より短かか った。これら 2 例では, 房室結節での伝導遅延が 本頻拍での excitable gap である副伝導路付着部の 心房筋の不応期を脱するのに不十分であったため 
リエントリー路が形成されなかったものと考えら れた. 本研究では心房不応期を高位右房の単発早 期刺激法で求めたため, 副伝導路付着部心房筋の 正確な不応期が不明であるが，高位右房の不応期 を一つの指標にしても妥当な結果が得られた。

一方潜在性副伝導路症候群では副伝導路の順行 性伝導がないことより，リエントリーの必要条件 の一つである一方向性ブロックが既に存在する。 したがって房室結節での伝導遅延が生じればリエ ントリーが形成されることになる，本研究では房 室結節内に二重伝導路を有する 4 例全例において, 房室結節での伝導が fast pathway から slow pathway 経由に移行した時点で直ちに心房エコーが生 じた. 早期刺激時の房室伝導時間は fast pathway

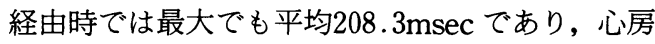
有効不応期 (平均 $226.3 \mathrm{msec}$ ) より短く, slow pathway 経由となった早期刺激時では平均 250.0 $\mathrm{msec}$ と延長し, 心房の不応期を脱するのに十分な 伝導遅延が生じたため, リエントリー路が形成さ れたものと考えられた。

しかし房室結節内二重伝導路を有しない13例で は心房エコー出現直前の早期刺激時の房室伝導時 間は平均 $191.9 \mathrm{msec}$ であり, 心房エコー出現時の それは平均 $220.0 \mathrm{msec}$ とわずかに延長したのみで あり,いずれもこれら13例での心房不応期（平均 $226.3 \mathrm{msec}$ )より短かった. 房室伝導時間が心房不 応期よりわずかに短かったにもかかわらず心房工 コーが生じたことは，(1)早期刺激間隔の短縮によ るわずかな房室伝導時間の延長でも心房筋の不応 期を脱したか，あるいは(2)早期刺激間隔の短縮に より心房不応期が短縮したかのいずれかまたは両 者の併存が考えられる ${ }^{4}$. 前述のごとく本研究では 高位右房での単発早期刺激法を施行したのみであ るため, 早期刺激による副伝導路付着部の心房不 応期の短縮については検討できなかった，本研究 では房室伝導時間は原則として, 副伝導路近傍で の心房興奮から心室興奮までの時間を測定してお り，早期刺激により延長した房室伝導時間が心房 筋の不応期を凌駕したか否かは不明である。一般 に心房筋や心室筋のような fast fiber では刺激間隔 の短縮に伴い不応期の短縮することが知られてお り，2 連発早期刺激法により求められた心房不応 期が単発早期刺激法により求めた不応期より短縮 することが既に報告されている5ことから,これら
13例では早期刺激によるわずかの房室伝導時間の 延長でも早期刺激間隔のわずかな短縮による心房 筋不応期の短縮が生じ，リエントリーを形成する のに十分な伝導遅延になり得たものと考えられた。

\section{IV. 結語}

房室回帰頻拍においては, 副伝導路での一方向 性ブロックと房室および心室内での伝導遅延がリ エントリー路を形成する必要条件であるが, excitable gap としての心房の不応期の長さと房室伝導時 間の関係，すなわち心房筋の不応期を脱するのに 十分な伝導遅延がリエントリーを成立させる律則 因子であると考えられた。

[文献]

1) Wellens HJJ, Brugada P: Value of Programmed Stimulation of the Heart in Patients with the Wolff-Parkinson-White Syndrome In Tachycardias: Mechanisms, Diagnosis, Treatment. Edited by Josephson MK, Wellens HJJ, Philadelphia, Lea \& Febiger, 1984, 199

2) Waldo AL, Maclean WAH, Karp PB, Kouchoukos NT, James TN : Entrainment and Interruption of Atrial Flutter with Atrial Pacing; Studies in man following Open Heart Surgery. Circulation $56: 737,1977$

3) Pritchett WELC, Gallagher JJ, Scheinman M, Smith WM : Determinants of Antegrade Echo Zone in the Wolff-Parkinson-White Syndrome. Circulation $57: 671,1978$

4 ) Denes P, Wu D, Dhingra R, Pietras RJ, Rosen $\mathrm{KM}$ : The Effects of Cycle Length on Cardiac Refractory Periods in Man. Circulation 49: 32, 1974

5 ) Ohe T, Kamakura S, Matsuhisa M, Hirata Y, Sato I, Shimomura K : Limiting Factor for the Initiation of Reentrant Tachycardia in Concealed Wolff-Parkinson-White Syndrome. International J Cardiology $3: 207,1983$ 